\title{
НОВЫЕ НУКЛЕОЗИДЫ 2-ХЛОРАДЕНОЗИНА В КАЧЕСТВЕ АГОНИСТОВ АДЕНОЗИНОВЫХ А РЕЦЕПТОРОВ
}

\author{
М.Я. Берзина', Б.З. Елецкая', И.Д. Константинова', \\ А.И. Мирошников ${ }^{1}$, Д.С. Яковлев ${ }^{2,3}$, К.Т. Султанова ${ }^{2,3}$,
} Я.В. Агацарская ${ }^{2,3}$, Д.В. Мальцев ${ }^{2,3}$, Л.В. Науменко, А.В. Таран

${ }^{1}$ ФГБУН Институт биоорганической химии им. академиков М.М. Шемякина и Ю.А. Овчинникова РАН, Москва, Россия, 117997, Москва, ул. Миклухо-Маклая, 16/10.

2ГБУ Волгоградский медицинский научный центр, 400131 Россия, г. Волгоград, пл. Павших борцов, 1.

3ФГБОУ ВО Волгоградский государственный медицинский университет Минздрава России, 400131 Россия, г. Волгоград, пл. Павших борцов, 1.

DOI: 10.19163/MedChemRussia2021-2021-303

E-mail: berzina_maria@mail.ru

Осуществлен синтез серии новых модифицированных нуклеозидов 2-хлораденозина. В С6 положение гетероциклического основания были введены остатки природных хиральных аминокислот.

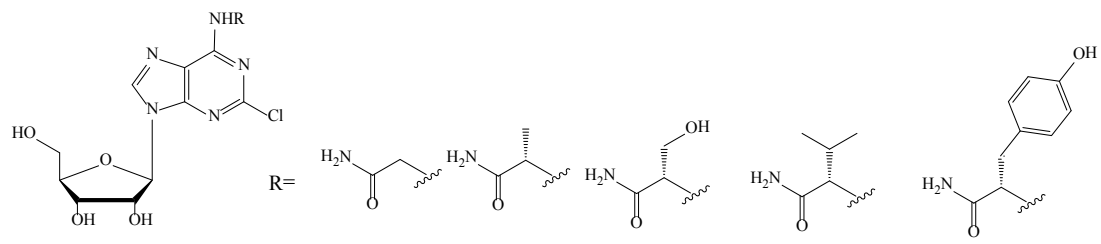

Проведен первичный скрининг активности новых модифицированных аналогов 2-хлораденозина по отношению к $\mathrm{A}_{1}$ аденозиновым рецепторам. Для соединений, содержащих остатки хиральных аминокислот в С6 положении, выявлено $\mathrm{A}_{1}$-миметическое действие. Тирозиновое, валиновое и сериновое производные оказались активны в концентрации 10 мкМ, однако их активность уступает аденозину, использованному в качестве референсного препарата. Наибольшая условная широта фармакологического действия и безопасности характерна для валинового и серинового производных.

Исследованные вещества в растворе с концентрацией $0.4 \%$ способны снижать внутриглазное давление (ВГД) у крыс, немного уступая по эффективности препаратам сравнения тимололу и бримонидину. Дополнительно показано, что для серинового производного характерно наличие анксиолитического действия.

Сериновое производное может представлять основу для дальнейшего конструирования и синтеза более активных соединений, способных стимулировать $\mathrm{A}_{1}$ аденозиновые рецепторы, в том числе с психотропным и антиглаукомным фармакологическим потенциалом.

Исследование частично выполнено за счет средств научного гранта

Волгоградской области, соглашение №6 om 10.12.2020 г. 